\title{
Effect of Cadmium Exposure among workers in Battery Industries
}

\section{EL-Sayed A.E.Hassanin ${ }^{1}$, Hamdy A.Mahdy El-Bassel ${ }^{2}$ and Amal H. Abd El-Razek ${ }^{3}$}

Department of Nutritional Biochemistry and Metabolism, National Nutrition Institute, Cairo, Egypt

\section{ABSTRACT \\ 7 he study aimed to assess the possible influence of long-term human occupational exposure to cadmium and smoking cigarettes at the time of exposure on renal and liver functions in battery manufacturing.} Methods: This cross-sectional study evaluated liver, kidney function, oxidative stress and lipid per oxidation among smoker and non smoker workers in battery manufacturing in Egypt. Multiple linear regression was conducted to investigate the association between cadmium exposure period and the serum levels of aspartate aminotransferase (AST), alanine aminotransferase (ALT), alkaline phosphatase (ALP), gamma-glutamyl transferase (GGT), albumin, creatinine, uric acid (UA), urea, cu/zn superoxide dismutase (cu/zn SOD), glutathione reductase (GSH) in RBCs, malondialdehyde (MDA), hemoglobin and $\beta 2$-microglobulin in urine, adjusting for smoking and the amount of cigarette smoked. Subjects were stratified into direct and indirect exposure according to their place of exposure. Results: our results show positive associations between exposure to cadmium and adverse effect on $\mathrm{Hb}, \mathrm{GSH}, \mathrm{UA}$ and GGT.

Keywords: Cadmium, Superoxide dismutase, Liver, Kidney, Toxicity, Environmental contaminant, Smoking. 


\section{INTRODUCTION}

Cadmium is a highly toxic metal with a very long half-life of 20-30 years in humans and accumulates in soft tissues, kidneys, and the liver. Specific mechanisms of cadmium toxicity are not well understood, however evidence suggests that cadmium affects DNA repair, and cell signaling and control. These effects lead to kidney damage, cancer, mutations, damage to hormone regulating mechanisms, reproductive disorders, and problems with cellular differentiation (Rani et al., 2014). Cadmium (Cd) is an industrial and environmental pollutant. Worker exposure to cadmium can occur in all industry sectors but mostly in manufacturing and construction. Workers may be exposed during melting and refining of metals, and manufacturing batteries, plastics, coatings, and solar panels (Weidenhamer et al., 2011).

Tobacco is an important source of cadmium exposure for smokers, who have about twice as much cadmium in their bodies as nonsmokers. For nonsmokers, food is the major route of exposure to cadmium among the non-occupational population (Barański et al., 2014). In the environment, $\mathrm{Cd}$ is dangerous because humans consume both plants and animals that absorb $\mathrm{Cd}$ efficiently and concentrate it within their tissues (Stohs and Bagchi 1995). $\mathrm{Cd}$ shows different mechanisms of toxicity under different experimental conditions and in various species (Waisberg et al., 2003). Cd has been demonstrated to stimulate free radical production, resulting in oxidative deterioration of lipids, proteins and DNA, and initiating various pathological conditions in humans and animals (Waisberg et al., 2003). Once absorbed, $\mathrm{Cd}$ is rapidly cleared from the blood and concentrates in various tissues.

Chronic exposure to inorganic $\mathrm{Cd}$ results in accumulation of the metal mainly in the liver and kidneys, as well as in other tissues and organs causing many metabolic and histological changes, membrane damage, altered gene 
expression and apoptosis (Shaikh et al. 1999, Casalino et al. 2002, Waisberg et al., 2003). Both recent and long-standing studies have shown that exposure to cadmium can lead to cancers, bone problems, and neuro developmental disorders (Barański et al., 2014).

Aim of the study: The study aimed to assess the possible influence of long-term human occupational exposure to cadmium and smoking cigarettes at the time of exposure on renal and liver functions in battery manufacturing.

\section{SUBJECTS \& METHODS}

\section{Materials}

Chemicals and kits were purchased from Merkschuchardt chemical company (Hohenbrunn. Germany). Commercial kits were used for assessment of biochemical parameters. All other chemicals were of analytical grade.

\section{Subjects:}

The current study was conducted on 350 workers (participants) aged 22-60 years.
Workers were classified into two groups, low exposure group at office, laboratory and supervisory personnel $(\mathrm{n}=98)$ (indirect exposure group); and a high exposure group as production workers (direct exposure group) with long histories of work in areas with substantial airborne cadmium $(n=252)$. These two groups were divided into subgroups according to duration of exposure and who are smoker and those who had never smoked. This study was conducted in (Chloride and Energizer Cos. represent batteries sector), Cairo and Alexandria, Egypt.

\section{Experimental Design:}

Study protocols were reviewed and approved by the ethic committee of National Nutrition Institute in Egypt and consents were obtained from all participants. All participants were interrogated using questionnaire in order to have detailed information about the age, medical history of (liver, renal diseases and diabetes), work period $(<5$ years, represent 
"298 cases and $>5$ years, represent 52 cases) and smoking habits (smokers and amount of cigarettes smoked/day ">20or $<20$ cigarettes per day"). Blood pressure was measured twice in a sitting position after $5 \mathrm{~min}$ rest, and the average was recorded, those have blood pressure 140/100 $\mathrm{mm} \mathrm{Hg}$ or more were considered hypertensive case. Random venous blood samples $10 \mathrm{ml}$, were collected from the individuals (Participants) in a tube containing anti-coagulant (EDTA). Hemoglobin ( $\mathrm{Hb}$ ) and glutathione reductase (GSH) in RBCs were determined immediately in the field using whole blood; the rest of the sample was centrifuged for 10 min. at $3000 \mathrm{rpm}$ to obtain plasma. The plasma was divided in 3 ependurf tubes to estimate the liver, kidney functions and lipid peroxidation (MDA). The RBCs were washed twice by saline for cu/zn SOD determination. The plasma, washed RBCs and urine collected were stored at $-40 \dot{\mathrm{C}}$ till analysis. Urinary $\beta 2$ microglobulin, liver and kidney functions were performed only for individuals who were diagnosed as hypertensive case (about 39\% of participants).

\section{Biochemical Analyses}

The

following parameters were determined: Hemoglobin ( $\mathrm{Hb} \%)$ according to Hunter, (1978), serum aspartate amino transferase (AST) and alanine amino transferase (ALT) according to Reitman and Frankel (1957). alkaline phosphatase (ALP) according to Kochmar and Moss (1976), gamma glutamyltransferase (GGT) according to (Webster, 1974), albumin according to (Doumas, 1971), blood urea, creatinine and uric acid were carried out according to Patton and Crouch (1977), Tietz (1986) and Tietz (1994) respectively.

malondialdehyde (MDA) was determined according to Uchiyama and Mihara (1978), Glutathione reductase activity was assayed according to Smith et al. (1988), erythrocyte copper and zinc supper oxide dismutase (cu/zn SOD) according to Winterbourne et al. (1975) and 
$\beta 2$-microglobulin according to

Poulik and Reisfeld (1975).

Since, the biochemical analysis for $\mathrm{Hb}, \mathrm{GSH}, \mathrm{MDA}$ and SOD were done for all workers (direct and indirect exposure). While, the other biochemical analysis (Urinary $\quad \beta 2-$ microglobulin, ALT, AST, ALP, GGT, Albumin, Urea, Creatinine and Uric acid) were done for sub-samples (136 cases _39\%, 50 cases according to blood pressure (high blood pressure).

\section{Statistical analysis}

The results were expressed as mean \pm SD. Data were analyzed by one way analysis of variance (ANOVA). The Differences between means were tested for significance using least significant difference (LSD) test at $\mathrm{P}<0.05$ (Steel and Torri, 1980).

\section{RESULTS}

Tables (1\&2) shows the results of indirect and direct exposure for $(\mathrm{Hb} \%, \mathrm{GSH}, \mathrm{MDA}$ and $\mathrm{Cu} / \mathrm{Zn} \mathrm{SOD}$ ), there was no significant difference in $\mathrm{Hb}$ for $<5,>5$ years of indirect exposure subjects There were significant difference for smokers $<20$ cigarettes between direct and indirect exposure. Also, there was significant difference between non-smokers direct and indirect exposure for $>5$ years.

However, there was significant difference between workers in GSH for non smokers $<5,>5$ years of indirect exposure subjects; there was no significance difference between smokers <5, >5 years workers on indirect exposure subjects. Also, there was significant difference in $\mathrm{Cu} / \mathrm{Zn}$ SOD for non-smokers and smokers <5 years of indirect exposure.

From Table (2) it could be seen that there was significant difference in $\mathrm{Hb}$ levels between smokers and non-smokers <5, $>5$ years. However, there was significant difference in GSH between smokers and nonsmokers of $>5$ years direct exposure, also between $<5,>5$ years of direct exposure for both non-smokers and smokers >20 cigarettes. On the other hand, there was significant difference in the level of MDA between smokers and non-smokers of 
direct

exposure.

The concentration of $\mathrm{Cu} / \mathrm{Zn} \mathrm{SOD}$ was demonstrated to be significant different between non-smokers for $<5,>5$ years direct exposure.

Kidney functions of indirect and direct exposure were shown in tables $(3 \& 4)$. It could be seen from Table 4 that there was significant difference in serum creatinine for smokers and non-smokers of $<5$ years exposure. There were no significant difference in blood urea and $\beta 2$-microglobulin in urine for smokers and nonsmokers of $<5$ years exposure. However, significant difference in UA concentrations were observed between $<5,>5$ years of exposure, also between smoker and non-smoker of $<5$ years exposure.

Serum concentrations of liver functions of indirect and direct exposure were represented in tables (5\&6). From Table 5, there was significant difference in serum albumin between smokers $<20$ cigarettes and nonsmokers of $<5$ years indirect exposure. There was significant difference in AST for smokers >
20 cigarettes of $<5$ years direct and indirect exposure.

From Table 6 we can see that there was significant difference in s. Albumin, AST and ALP for non-smokers between $<5$ and $>5$ years of exposure. Also, there was significant difference in AST for smokers $>20$ cigarettes of $<5$ and $>5$ years of exposure.

\section{DISCUSSION}

Cadmium was widely used in industry since one decade ago, where its health risks were recognized (Eriksen, et al., 2015). Many current observational studies reported positive associations between exposure to $\mathrm{Cd}$ and adverse effect on hemoglobin, study by (Chen, et al., 2015) revealed that the $\mathrm{Hb}$ of men with the highest level of blood cadmium decreased to $10.7 \mathrm{~g} / \mathrm{L}$ compared to those with the lowest level of blood cadmium, which is consistent with the findings of the present study. Other study by (Hounkpatin et al., 2013) conducted on rats reported that there is a significant decrease in 
the red blood cell $(\mathrm{RBC})$ count \& haemoglobin $(\mathrm{Hb})$ concentrations, packed cell volume $(\mathrm{PCV}), \quad$ mean corpuscular volume (MCV) \& mean corpuscular haemoglobin $(\mathrm{MCH})$, leading to anemia, on cadmium exposure.

The toxicity of $\mathrm{Cd}$ is associated with oxidative damage caused by the production of ROS (Ivanina et al., 2008). GSH is considered a primary defense mechanism against $\mathrm{Cd}$, since its cysteine thiol group rapidly reduces the metal by forming a stable GS-Cd complex. Thus, the excessive consumption of $\mathrm{GSH}$ in metal reduction, chelation and oxidation by ROS leads to its significant depletion following exposure to high levels of $\mathrm{Cd}$, compromising detoxification (Rana et al., (2002). On the other hand, Study by Sherif et al. (2010) conducted on rats concluded that $\mathrm{Cd}$ exposure significantly increased the lipid peroxidation marker malondialdehyde (MDA), while the antioxidant enzyme glutathione reductase (GSH) significantly decreased. The presented results were in accordance with various previous reports suggesting that Cd can cause oxidative stress. The results in our study show that in indirect cadmium exposure has no change in kidney functions neither among non smokers nor smokers. These results are in line with the result by Mortada et al. (2004), who concluded that exposure to cadmium due to cigarettes smoke is not high enough to produce nephrotoxicity. However, it may incite signs of nephrotoxicity in the presence of risk factors for kidney diseases.

The kidney is the principal organ targeted by chronic exposure to cadmium. Cadmium nephrotoxicity may follow chronic inhalation or ingestion. Data from human studies suggest a latency period of approximately 10 years before clinical onset of renal damage, depending on intensity of exposure (Ikeda, 2005).

The data obtained show no significant association between duration of occupational exposure to cadmium and 
smoking cigarette at the time of exposure on batteries workers and urinary $\beta 2$ - microglobulin levels was found in our study. This could be due to the fact that the level of cadmium, which has considerable effect on tubular function, is not high enough in batteries sector. We believe more studies on urinary $\beta 2$-microglobulin levels and other low molecular weight proteins are required to determine the effects of cadmium exposure in batteries sectors on renal function. Also the appropriateness of using urinary $\beta 2$ microglobulin levels as a biomarker for tubular dysfunction in batteries workers deserves more research.

Our results are in line with the results by Smith et al. (1988) who concluded that kidney function status between the high and low exposure groups showed a significant reduction in creatinine clearance, and increased uric acid and beta2 microglobulin excretion by the high group.

The liver plays a crucial role in detoxification and excretion of many endogenous and exogenous substances, and its detoxification systems are easily overloaded. The outcome of cadmium exposure on the liver is hepatic cell changes (Elias, 2013). The present study reveals that an elevation in serum liver enzyme levels in direct cadmium exposure. Our results agreed with that by kang et al. (2013) who showed that environmental cadmium exposures are associated with an elevation in serum liver enzyme levels in Korean adults. The significant increase in GGT between smokers and nonsmokers is agreed with that of Milnerowicz et al. (2010) who observed that the activities of GGT were significantly increased in the group who smoked 20 or more 20 cigarettes a day in comparison to the non-smoking group. Also, Lee and Jacobs (2009) who reported that serum GGT within its reference range was linearly associated with important environmental pollutants, including lead and cadmium. 


\section{CONCLUSION}

Adverse health effects of cadmium occur due to acute exposure and chronic exposure. Acute exposure to cadmium usually occurs when occupational workers are exposed to high doses of cadmium in industrial processes. The outcomes due to acute exposure are oxidative stress, anemia, renal and liver dysfunctions.

\section{RECOMMENDATIONS:}

Workers must be informed about the potential health effects associated with exposure to cadmium. This should include counseling on the effect of smoking on cadmium exposure.

\section{REFERENCES}

Barański, M., SrednickaTober, D., Volakakis, N., Seal, C., Sanderson, R., Stewart, G., Benbrook, C., Biavati, B., Markellou, E. and Giotis, C. (2014):

Higher antioxidant and lower cadmium concentrations and lower incidence of pesticide residues in organically grown crops: a systematic literature review and metaanalyses. $\mathrm{Br} \quad J \quad \mathrm{Nutr}$. 112(5):794-811.

Casalino, E., Calzaretti, G., Sblano, C. and Landriscina, C. (2002):

Molecular inhibitory

mechanisms of antioxidant enzymes in rat liver and kidney by cadmium. Toxicology, 179: $37-50$.

Chen, X., Zhou, H., Li, X., Wang, Z., Zhu, G. and Jin, T. (2015):

Effects of lead and cadmium co-exposure on hemoglobin in a Chinese population. Environ Toxicol Pharmacol., 39 (2):758-63.

Doumas, B.T., Watson, W.A. and Biggs, H.G. (1971):

Albumin standards and the measurement of serum albumin with bromcresol green. Clin. Chem. Acta., 31: 87-96. 
Elias, D. (2013):

Hepatotoxicity of

Cadmium and Roles of Mitigating Agents. British Journal of Pharmacology and Toxicology. 4(6): 222-231.

Eriksen, K. T. et al. (2015):

Dietary cadmium intake and risk of prostate cancer: a Danish prospective cohort study. BMC cancer 15 , 177: 1153-9.

Hounkpatin, Y., Edorh, A., Guédénon, P., Alimba, G., Ogunkanmi, A., Dougnon V., Boni, G., Aissi, A., Montcho, S., Loko, F., Ouazzani, N., Mandi, L., Boko, M. and Creppy, E. (2013):

Haematological evaluation of Wistar rats exposed to chronic doses of cadmium, mercury and combined cadmium and mercury. African J. Biotechnol., 12(23): 3731- 3737.

Hunter, E. (1978):

Variable effects of iron status on the concentration of ferritin in rats plasma, liver, and spleen. J. Nutr., 108: 497-505.

Ikeda, M., T. Ezaki, et al. (2005):

The threshold cadmium level that causes a substantial increase in urine of general populations. Tohoku J. Exp. Med., 205: 247-261.

Ivanina, A.V., Cherkasov, A.S., Sokolova, I.M. (2008):

Effects of cadmium on cellular protein and glutathione synthesis and expression of stress proteins in eastern oysters, Crassostrea virginica Gmelin. J. Exp. Biol., 211: 577-586.

Kang, M., Cho, S., Lim, Y., Sep, J. and Hong, Y. (2013):

Effects of environmental cadmium exposure on liver function in adults. Occup. Environ. Med., 70(4): 26873.

Kochmar, F. and Moss, W. (1976): 
Fundamentals of clinic.

Chem.N.W., P. (604),

W.B. saunders and company,

Philadelphia.PA.

Lee, D.H. and Jacobs, D.R. (2009):

Hypothesis: a unifying mechanism for nutrition and chemicals as lifelong modulators of DNA hypomethylation. Environ Health Perspect., 117(12):1799-802.

Milnerowicz, H., Bizoń, A. and Stasiak, K. (2010):

Activity of gammaglutamyltransferase in blood of smoking and non-smoking smelters. Przegl Lek., 67(10): 91023.

Mortada, W., Sobh, M. and El-Defrawy, M. (2004):

The exposure to cadmium, lead and mercury from smoking and its impact on renal integrity. Med Sci Monit., 10(3):CR112-6.
Patton, C.J. and Crouch, S.R. (1977):

Enzymatic determination of urea (according to the urease modified Berthelot reaction). Anal. Chem., 49: 464-469.

Poulik, M. and Reisfeld, R. (1975):

"Beta2-

microglobulins," Contem porary Topics in Molecular Immunology, 4: 157-204.

Rana, S., Allen, T., Singh, R. (2002):

Inevitable glutathione, then and now. Indian J. Exp. Biol., 40: 706-716.

Rani, A., Kumar, A., Lal, A. and Pant M. (2014):

Cellular mechanisms of cadmium-induced toxicity: a review. Int. J. Environ. Health Res., 4: 378-99.

Reitman, S. and Frankel, S. (1957):

Colorimetric method for the vitro determination of 
GOT and GPT in serum or plasma. Am. J. Clin. Path., 28: 56-63.

Shaikh, Z., Vu, T. and Zaman, K. (1999):

Oxidative stress as a mechanism of chronic cadmium-induced

hepatotoxicity and renal toxicity and protection by antioxidants. Toxicol. Appl. Pharmacol., 154: 256-263.

Sherif, A., Samir, A. and Bassem, M. (2010):

Biophysical Approach of Anemia in Cadmium Induced Toxicity of Rats. Med. J. Cairo Univ., 78(1): 47-52.

Smith, K., Vierheller, L. and Thorne, A. (1988):

Assay of glutathione reductase in crude tissue homogenates using 5, 5'dithiobis(2- nitrobenzoic acid). Anal Biochem., 175: 408-413.
Steel, G. and Torri, H. (1980):

Statistical and computational models of the visual world paradigm: Growth curves and individual differences. J. of Memory and Language, 59(4), 475-494.

Stohs, S. and Bagchi, D. (1995):

Oxidative mechanisms in the toxicity of metal ions. Free Radic. Biol. Med., 18: 321-336.

Tietz NW. (1994):

Fundamentals of Clinical Chemistry. 2nd Edn., NW Tietz, USA.

Tietz NW. (1986):

Textbook of Clinical Chemistry. WB Saunders, Philadelphia, pp1271-1281.

Uchiyama, M. and Mihara, M. (1978):

Determination

of malonaldehyde precursor in tissues by thiobarbituric acid testes, 
Anal. Biochem., 86:271278.

Winterbourne, C., Howkins,

Waisberg, M., Joseph, P., R.E., Brain, M. and Carrell, Hale, B. and Beyersmann, D. (2003): R.W. (1975):

Molecular and cellular mechanisms of cadmium carcinogenesis: a review. The estimation of red cell superoxide dismutase activity. J. Lab. Clin. Med., 85:337Toxicology, 192: 95-117. 341.

Webster, D. (1974):

Clin. Chem. Acta, 53, 109.

Weidenhamer, J., Miller, J., Guinn, D. and Pearson, J. (2011):

Bioavailability of

Cadmium in Inexpensive Jewelry. Environ. Health Perspect., 119 (7): 10291033. 
Table (1): Effect of cadmium exposure on (Hb GSH, MDA and Cu/Zn SOD) indirect exposure battery workers

\begin{tabular}{|c|c|c|c|c|c|c|}
\hline \multirow{3}{*}{$\begin{array}{l}\text { Parameters } \\
\text { Exposure } \\
\text { Period }\end{array}$} & \multicolumn{3}{|c|}{$<5$ YEARS } & \multicolumn{3}{|c|}{$>5$ YEARS } \\
\hline & \multirow[b]{2}{*}{ Non-Smoker } & \multicolumn{2}{|c|}{ Smoker } & \multirow[b]{2}{*}{ Non-Smoker } & \multicolumn{2}{|c|}{ Smoker } \\
\hline & & $\begin{array}{l}<20 \\
\text { cigarettes }\end{array}$ & $\begin{array}{l}>20 \\
\text { cigarettes }\end{array}$ & & $\begin{array}{c}<20 \\
\text { cigarettes }\end{array}$ & $\begin{array}{c}>20 \\
\text { cigarettes }\end{array}$ \\
\hline NO, Case & 55 & 16 & 10 & 5 & 6 & 6 \\
\hline Hb $\quad g / L$ & $14.7 \pm 1.9$ & $14.9 \pm 0.97^{\mathbf{b}}$ & $14.16 \pm 1.2$ & $14.84 \pm 0.8^{\mathbf{b}}$ & $\begin{array}{c}14.7 \pm \\
1.59\end{array}$ & $\begin{array}{c}14.8 \pm \\
0.72\end{array}$ \\
\hline $\begin{array}{l}\text { GSH } \\
\mathrm{mg} / \mathrm{dl}\end{array}$ & $34.5 \pm 8.8^{\mathrm{a}}$ & $38.8 \pm 7.7$ & $38.8 \pm 8.5$ & $\begin{array}{c}19.34 \\
\pm 3.732^{\mathrm{a}}\end{array}$ & $\begin{array}{l}21.1 \\
\pm 5.6\end{array}$ & $\begin{array}{c}25 \pm \\
6.2\end{array}$ \\
\hline $\begin{array}{l}\text { MDA } \\
\mathrm{nmol} / \mathrm{ml}\end{array}$ & $1.8 \pm 0.41$ & $1.19 \pm 0.31$ & $1.366 \pm 0.39$ & $1.9 \pm 0.35$ & $\begin{array}{c}1.06 \\
\pm 0.14\end{array}$ & $\begin{array}{c}1.78 \\
\pm 0.21\end{array}$ \\
\hline $\begin{array}{l}\mathrm{Cu} / \mathrm{Zn} \text { SOD } \\
\mathrm{U} / \mathrm{ml}\end{array}$ & $126.5 \pm 20.4 \mathrm{c}$ & $171.9 \pm 23.2$ & $161.1 \pm 24.5 c$ & $172.2 \pm 38.23$ & $\begin{array}{l}168.2 \\
\pm 25.6\end{array}$ & $\begin{array}{c}184.0 \pm \\
36.9\end{array}$ \\
\hline
\end{tabular}

a $\longrightarrow$ significant between $<5,>5$ years of exposure

$\mathrm{b} \longrightarrow$ significant between direct and indirect exposure

$\mathrm{c} \longrightarrow$ significant between smoker and non-smoker 
Table (2): Effect of cadmium exposure on (Hb, GSH, MDA and Cu/Zn SOD) direct exposure battery workers

\begin{tabular}{|c|c|c|c|c|c|c|}
\hline \multirow{3}{*}{$\begin{array}{c}\text { Parameters } \\
\text { Exposure } \\
\text { Period }\end{array}$} & \multicolumn{3}{|c|}{$<5$ YEARS } & \multicolumn{3}{|c|}{.$>5$ YEARS } \\
\hline & \multirow[b]{2}{*}{ Non-Smoker } & \multicolumn{2}{|c|}{ Smoker } & \multirow{2}{*}{$\begin{array}{c}\text { Non- } \\
\text { Smoker }\end{array}$} & \multicolumn{2}{|c|}{ Smoker } \\
\hline & & $\begin{array}{c}<20 \\
\text { cigarettes }\end{array}$ & $\begin{array}{c}>20 \\
\text { cigarettes }\end{array}$ & & $\begin{array}{c}<20 \\
\text { cigarettes }\end{array}$ & $\begin{array}{c}>20 \\
\text { cigarettes }\end{array}$ \\
\hline NO, Case & 103 & 74 & 40 & 18 & 10 & 7 \\
\hline $\mathrm{Hb} \quad \mathrm{g} / \mathrm{L}$ & $14.9 \pm 2.1^{\mathrm{a}}$ & $14.1 \pm 1.58^{\mathbf{b}}$ & $\begin{array}{c}14.61 \pm \\
1.49^{\mathrm{a}}\end{array}$ & $\begin{array}{l}15.92 \pm \\
0.904^{\mathrm{ab}}\end{array}$ & $14.7 \pm 1.8$ & $\begin{array}{c}15.74 \pm \\
0.84^{\mathrm{a}}\end{array}$ \\
\hline GSH $\mathrm{mg} / \mathrm{dl}$ & $32.56 \pm 9.09^{\mathrm{ac}}$ & $38.64 \pm 10.9$ & $\begin{array}{c}39.10 \pm 8.60^{\mathrm{a}} \\
\mathbf{c}\end{array}$ & $\begin{array}{c}23.26 \pm 6.5 \\
4^{\mathrm{a}}\end{array}$ & $18.3 \pm 3.9$ & $25.65 \pm 10^{\mathrm{a}}$ \\
\hline $\begin{array}{l}\text { MDA } \\
\mathrm{nmol} / \mathrm{ml}\end{array}$ & $1.86 \pm 0.38 \mathrm{c}$ & $1.66 \pm 0.36$ & $1.40 \pm 0.24 \mathrm{c}$ & $1.97 \pm 0.39$ & $1.69 \pm 0.23$ & $1.12 \pm 0.19$ \\
\hline $\begin{array}{l}\text { Cu/Zn SOD } \\
U / \mathrm{ml}\end{array}$ & $\begin{array}{c}133.77 \pm 33.4 \mathrm{a} \\
\mathrm{c}\end{array}$ & $\begin{array}{c}178.17 \pm 27 . \\
57\end{array}$ & $\begin{array}{c}166.05 \pm 32 . \\
6 c\end{array}$ & $\begin{array}{c}178.82 \pm 23 \\
\mathrm{a}\end{array}$ & $\begin{array}{c}148.00 \pm 23 . \\
6\end{array}$ & $164.5 \pm 46.4$ \\
\hline
\end{tabular}


Table (3): Effect of cadmium exposure on kidney functions indirect exposure battery workers.

\begin{tabular}{|c|c|c|c|c|c|c|}
\hline \multirow{3}{*}{$\begin{array}{l}\text { Parameters } \\
\text { Exposure } \\
\text { Period }\end{array}$} & \multicolumn{3}{|c|}{$<5$ YEARS } & \multicolumn{3}{|c|}{$>5$ YEARS } \\
\hline & \multirow[b]{2}{*}{ Non-Smoker } & \multicolumn{2}{|c|}{ Smoker } & \multirow{2}{*}{$\begin{array}{c}\text { Non- } \\
\text { Smoker }\end{array}$} & \multicolumn{2}{|c|}{ Smoker } \\
\hline & & $\begin{array}{c}<20 \\
\text { cigarettes }\end{array}$ & $\begin{array}{c}>20 \\
\text { cigarettes }\end{array}$ & & $\begin{array}{c}<20 \\
\text { cigarettes }\end{array}$ & $\begin{array}{c}>20 \\
\text { cigarettes }\end{array}$ \\
\hline NO, Case & 32 & 6 & 12 & - & - & - \\
\hline Creat. mg/dl & $\begin{array}{c}0.878 \pm \\
0.143\end{array}$ & $\begin{array}{c}0.95 \pm \\
0.101\end{array}$ & $\begin{array}{c}0.90 \pm \\
0.282\end{array}$ & ---- & ---- & ---- \\
\hline Urea mg/dl & $33.50 \pm 9.112$ & $\begin{array}{c}30.66 \pm \\
8.041\end{array}$ & $\begin{array}{c}28.50 \pm \\
3.45\end{array}$ & ---- & ---- & ---- \\
\hline UA $\quad \mathrm{mg} / \mathrm{dl}$ & $4.650 \pm 1.04$ & $\begin{array}{c}4.033 \pm 1 \\
09\end{array}$ & $\begin{array}{c}4.550 \pm \\
0.212\end{array}$ & ---- & ---- & ---- \\
\hline $\begin{array}{l}\beta 2- \\
\text { microglobulin } \\
\text { in urine } \mu \mathrm{g} / \mathrm{ml}\end{array}$ & $\begin{array}{c}0.067 \pm \\
0.008\end{array}$ & $\begin{array}{c}0.083 \pm \\
0.001\end{array}$ & $0.02 \pm 0.003$ & ---- & ---- & ---- \\
\hline
\end{tabular}


Table (4): Effect of cadmium exposure on kidney functions direct exposure battery workers.

\begin{tabular}{|c|c|c|c|c|c|c|}
\hline \multirow{3}{*}{$\begin{array}{l}\text { Parameters } \\
\text { Exposure } \\
\text { Period }\end{array}$} & \multicolumn{3}{|c|}{$<5$ YEARS } & \multicolumn{3}{|c|}{.$>5$ YEARS } \\
\hline & \multirow{2}{*}{$\begin{array}{l}\text { Non- } \\
\text { Smoker }\end{array}$} & \multicolumn{2}{|c|}{ Smoker } & \multirow{2}{*}{$\begin{array}{c}\text { Non- } \\
\text { Smoker }\end{array}$} & \multicolumn{2}{|c|}{ Smoker } \\
\hline & & $\begin{array}{c}<20 \\
\text { cigarettes }\end{array}$ & $\begin{array}{c}>20 \\
\text { cigarettes }\end{array}$ & & $\begin{array}{c}<20 \\
\text { cigarettes }\end{array}$ & $\begin{array}{c}>20 \\
\text { cigarettes }\end{array}$ \\
\hline NO, Case & 39 & 18 & 16 & 13 & - & - \\
\hline Creat. mg/dl & $\begin{array}{c}0.848 \pm \\
0.269^{\mathrm{c}}\end{array}$ & $\begin{array}{c}1.055 \pm \\
0.125\end{array}$ & $\begin{array}{c}1.093 \pm \\
0.154^{\mathrm{c}}\end{array}$ & $\begin{array}{c}0.766 \pm \\
0.088\end{array}$ & ---- & ---- \\
\hline Urea $\mathrm{mg} / \mathrm{dl}$ & $\begin{array}{l}34.33 \\
\pm 8.76\end{array}$ & $37.66 \pm 9.75$ & $31.25 \pm 8.76$ & $40.0 \pm 8.08$ & ---- & ---- \\
\hline UA $\quad \mathbf{m g} / \mathbf{d l}$ & $\begin{array}{l}4.95 \pm \\
1.06^{\text {ac }}\end{array}$ & $3.98 \pm 1.05^{\mathbf{c}}$ & $4.437 \pm 1.02$ & $7.83 \pm 2.0^{\mathrm{a}}$ & ---- & ---- \\
\hline $\begin{array}{l}\beta 2- \\
\text { microglobulin } \\
\text { in urine } \mu \mathrm{g} / \mathrm{ml}\end{array}$ & $\begin{array}{c}0.064 \pm \\
0.014\end{array}$ & $\begin{array}{c}0.061 \pm \\
0.005\end{array}$ & $\begin{array}{c}0.059 \pm 0.00 \\
4\end{array}$ & $\begin{array}{c}0.073 \pm \\
0.018\end{array}$ & ---- & ---- \\
\hline
\end{tabular}


Table (5): Effect of cadmium exposure on liver functions in indirect exposure battery workers

\begin{tabular}{|c|c|c|c|c|c|c|}
\hline \multirow{3}{*}{$\begin{array}{c}\text { Parameters } \\
\text { Exposure } \\
\text { Period }\end{array}$} & \multicolumn{3}{|c|}{$<5$ YEARS } & \multicolumn{3}{|c|}{$>5$ YEARS } \\
\hline & \multirow[b]{2}{*}{ Non-Smoker } & \multicolumn{2}{|c|}{ Smoker } & \multirow{2}{*}{$\begin{array}{l}\text { Non- } \\
\text { Smoker }\end{array}$} & \multicolumn{2}{|c|}{ Smoker } \\
\hline & & $\begin{array}{c}<20 \\
\text { cigarettes }\end{array}$ & $\begin{array}{c}>20 \\
\text { cigarettes }\end{array}$ & & $\begin{array}{c}<20 \\
\text { cigarettes }\end{array}$ & $\begin{array}{c}>20 \\
\text { cigarettes }\end{array}$ \\
\hline NO, Case & 32 & 16 & 12 & -- & -- & -- \\
\hline Albumin $g / L$ & $4.221 \pm 0.659^{c}$ & $\begin{array}{l}3.533 \pm \\
0.445^{\mathrm{c}}\end{array}$ & $3.90 \pm 0.414$ & ---- & ---- & ---- \\
\hline AST IU/L & $26.0 \pm 5.50$ & $22.0 \pm 3.84$ & $\begin{array}{c}23.00 \\
\pm 5.71^{b}\end{array}$ & --- & ---- & ---- \\
\hline ALT IU/L & $17.0 \pm 8.06$ & $13.00 \pm 2.96$ & $\begin{array}{c}19.00 \pm \\
2.77\end{array}$ & --- & ---- & ---- \\
\hline $\begin{array}{l}\text { GGT } \\
\mu \mathrm{kat} / \mathrm{L}\end{array}$ & $17.0 \pm 3.54$ & $13.0 \pm 1.86$ & $26.0 \pm 3.12$ & ---- & ---- & ---- \\
\hline ALP IU/L & $112.57 \pm 21.62$ & $\begin{array}{c}102.40 \pm 18 \\
07\end{array}$ & $\begin{array}{l}126.00 \\
\pm 13.00\end{array}$ & ---- & ---- & ---- \\
\hline
\end{tabular}


Table (6): Effect of cadmium exposure on liver functions in direct exposure battery workers.

\begin{tabular}{|c|c|c|c|c|c|c|}
\hline \multirow[t]{3}{*}{$\begin{array}{l}\text { Parameters } \\
\text { Exposure } \\
\text { Period }\end{array}$} & \multicolumn{3}{|c|}{$<5$ YEARS } & \multicolumn{3}{|c|}{$>5$ YEARS } \\
\hline & \multirow[b]{2}{*}{ Non-Smoker } & \multicolumn{2}{|c|}{ Smoker } & \multirow{2}{*}{$\begin{array}{c}\text { Non- } \\
\text { Smoker }\end{array}$} & \multicolumn{2}{|c|}{ Smoker } \\
\hline & & $\begin{array}{c}<20 \\
\text { cigarettes }\end{array}$ & $\begin{array}{c}>20 \\
\text { cigarettes }\end{array}$ & & $\begin{array}{c}<20 \\
\text { cigarettes }\end{array}$ & $\begin{array}{c}>20 \\
\text { cigarettes }\end{array}$ \\
\hline NO, Case & 39 & 18 & 16 & 23 & ----- & 14 \\
\hline $\begin{array}{l}\text { Albumin } \\
\text { g/L }\end{array}$ & $4.43 \pm 0.727^{\mathbf{a}}$ & $4.05 \pm 0.80$ & $\begin{array}{c}4.225 \pm \\
0.95\end{array}$ & $\begin{array}{c}3.850 \pm \\
0.21^{\mathrm{a}}\end{array}$ & ---- & $4.12 \pm 0.85$ \\
\hline $\begin{array}{l}\text { AST } \\
\text { IU/L }\end{array}$ & $23.0 \pm 5.60^{\mathbf{a}}$ & $20.0 \pm 4.84$ & $19.0 \pm 3.7^{\mathbf{a b}}$ & $42.0 \pm 12.8^{\mathbf{a}}$ & ---- & $42.0 \pm 14.4^{\mathrm{a}}$ \\
\hline $\begin{array}{l}\text { ALT } \\
\text { IU/L }\end{array}$ & $15.55 \pm 3.168$ & $16.86 \pm 4.61$ & $11.94 \pm 2.92$ & $15.00 \pm 3.76$ & ---- & $9.0 \pm 1.2$ \\
\hline $\begin{array}{l}\text { GGT } \\
\mu \text { kat/L }\end{array}$ & $13.0 \pm 2.54^{\mathbf{b c}}$ & $16.40 \pm 1.85$ & $22.0 \pm 2.12^{c}$ & $25.00 \pm 3.09$ & ---- & $17.0 \pm 3.8$ \\
\hline $\begin{array}{l}\text { ALP } \\
\text { IU/L }\end{array}$ & $\begin{array}{c}112.57 \\
\pm 12.62^{\mathrm{a}}\end{array}$ & $\begin{array}{c}102.40 \pm \\
18.077\end{array}$ & $\begin{array}{c}126.0 \\
\pm 17.85\end{array}$ & $\begin{array}{c}78.66 \pm \\
9.237^{\mathrm{a}}\end{array}$ & ---- & $91.0 \pm 21.36$ \\
\hline
\end{tabular}




\section{تأثير التعرض للكادميوم في صناعة البطاريات}

السيد عبد الخالق حسنين، حمدي عبد النبي مهدي الباسل، أمال حامد عبد الرازق عمارة

المعهـ القومي للتغذية الملخص العربي

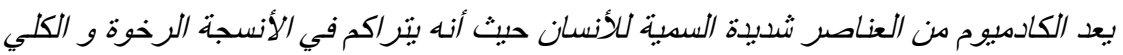

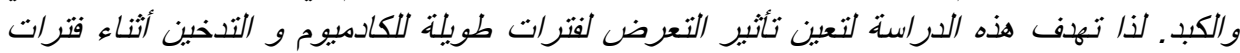

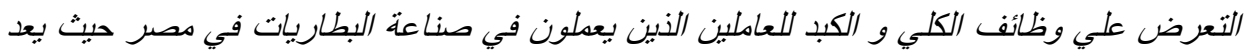

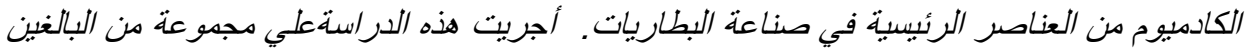

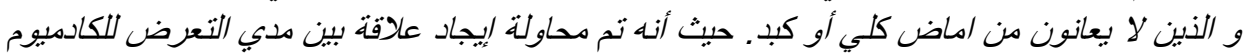

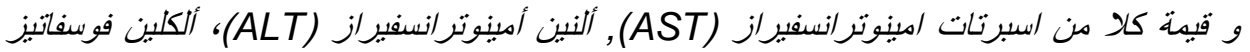
(ALP)

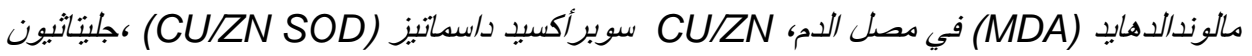

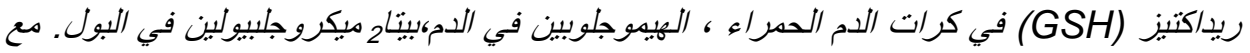

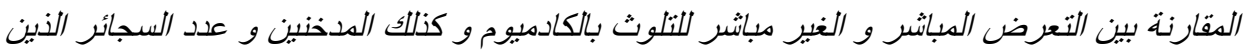

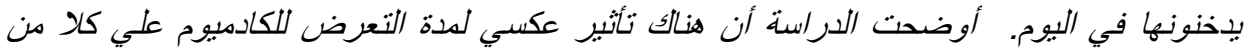
الهيموجلوبين GGT، UA, GSH، لذا بجب تقديم النصائح للعاملين في مجال البطاريات علي التأثبير السلبي للكادمبوم علي الصحة.

الكلمات المفتاحية: الكادمبوم - مضادات الاكسدة في الكبب والكلى ـ التسمم- ملوثات البيئة- التدخبن 